\title{
Social Welfare in Third World Development
}


Other books by Howard Jones include

Race, Crime and Culture: A Study in a Developing Country

Issues in Social Welfare 


\section{Social Welfare in Third World Development}

Howard Jones

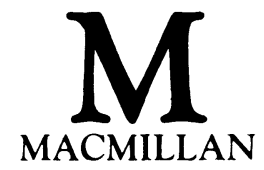


All rights reserved. No reproduction, copy or transmission of this publication may be made without written permission.

No paragraph of this publication may be reproduced, copied or transmitted save with written permission or in accordance with the provisions of the Copyright Act 1956 (as amended), or under the terms of any licence permitting limited copying issued by the Copyright Licensing Agency, 33-4 Alfred Place, London WC1E 7DP.

Any person who does any unauthorised act in relation to this publication may be liable to criminal prosecution and civil claims for damages.

First published 1990

Published by

MACMILLAN EDUCATION LTD

Houndmills, Basingstoke, Hampshire RG21 2XS

and London

Companies and representatives

throughout the world

Typeset by Footnote Graphics, Warminster, Wilts

British Library Cataloguing in Publication Data

Jones, Howard

Social welfare in Third World development.

1. Developing countries. Welfare services

1. Title

361'.9172'4

ISBN 978-0-333-48843-0

ISBN 978-1-349-20525-7 (eBook)

DOI 10.1007/978-1-349-20525-7 
To my wife, Bess, who has contributed so much over many years not only to this, but also to my other books 


\section{Contents}

List of Tables

viii

List of Figures $\quad$ x

List of Exhibits $\quad$ xi

Acknowledgements xii

Introduction $\quad 1$

1 The Economic Debate 9

2 Poverty $\quad 36$

3 The Rural Majority $\quad 53$

4 Third World Cities $\quad 78$

5 Development and Health 106

6 Policies for Health 124

7 The Educational Scene 149

8 Ends and Means in Education 167

9 Role of the Social Worker 189

10 The Community and its Youth 208

11 Women's Rights $\quad 222$

12 Population Policies $\quad 242$

13 Government and Misgovernment 259

14 Social Welfare in Development 281

References and Author Index 296

$\begin{array}{ll}\text { Subject Index } & 318\end{array}$ 


\section{List of Tables}

3.1 Rural and urban populations, Estimates for 1980, 1985 and 2000, (in millions), more and less developed regions

4.1 Estimated percentages of the population living in urban areas, more and less developed regions

4.2 Percentage annual urban growth rates, more and less developed regions

5.1 Life expectancy at birth (years), developed and less developed countries, 1965 and 1986

5.2 Infant and child death rates (per 1000) in developed and less developed countries, 1965 and 1985

5.3 Number of deaths in major categories of cause by WHO region (thousands)

5.4 Child mortality according to characteristics of parents, Tanzania, 1973

5.5 Proportion of children dying by age 2 years in various less developed countries, according to mother's level of education

6.1 Hospital beds per 10000 population, developed and developing countries

6.2 Population for each medical person, developed and developing countries

7.1 Literacy rates (per cent) for various groups of countries, 1960 and 1980

7.2 Primary school enrolment ratios according to the country's per capita income level, 1960-75

7.3 Primary school enrolment ratios for 1980 and 1985 and estimates for subsequent years 
7.4 Percentage rates of social return to education

7.5 Families of 1954 Indian graduates by average monthly family income

7.6 Primary school enrolments as a percentage of each income group in various developing countries

7.7 Percentage of females in total school enrolments in underdeveloped countries

8.1 Results of UNESCO/UNDP literacy programme, selected countries

12.1 Crude birth and death rates per thousand of population for the more developed and less developed countries, 1950-90

12.2 Population in 1950 and 1980, and population forecasts to 2025 as assessed in 1984, more and less developed countries (millions) 


\section{List of Figures}

1.1 Net resource transfers to developing countries 1973 to $1987 \quad 11$

1.2 Real commodity prices $1970-87 \quad 24$

3.1 Rural population affected by severe desertification (millions) 64

3.2 Percentage of landless and near-landless rural $\begin{array}{ll}\text { labour force } & 70\end{array}$

$\begin{array}{lll}3.3 & \text { Unproductive land } & 75\end{array}$

6.1 Comparative health costs - community, preventive, curative 137

7.1 Comparative education costs - primary, secondary, higher 157

10.1 Share of youth population: developing countries 214

12.1 Average age at marriage for females in various underdeveloped countries 251

12.2 Contraception and infant mortality 255 


\section{List of Exhibits}

1.1 Structuralist empiricism 20

1.2 A Marxist case for capitalism 32

2.1 Social security in South-East Asia 44

2.2 Social insurance and social justice 46

3.1 Famine and food aid 73

4.1 Growth of settlements 90

4.2 Squatting as exploitation $\quad 102$

5.1 Mothers' education and child mortality rates $\quad 119$

6.1 Upgrading the barefoot doctor 133

6.2 Community mental health: the Geel experience $\quad 140$

7.1 Education and agricultural productivity 152

8.1 Shortcomings of literacy campaigns 177

8.2 A 'basic education' educational system 183

9.1 Duties of social workers 191

9.2 Care of the elderly: an indigenous experiment 203

11.1 Womens' share of work 224

11.2 Female separatism in the Arab world 228

13.1 Traditions and corruption 275 


\section{Acknowledgements}

This book owes much to individuals who have read particular chapters or have discussed parts of its subject matter with me. I should like particularly to mention $\mathrm{Mr}$ M. J. Shepperdson of University College, Swansea and Dr Paul Romaya and Ms H. R. Snee of the then University of Wales Institute of Science and Technology (now the University of Wales College of Cardiff).

My further debt to those who have contributed to the scientific literature on these subjects is obvious - particularly to those whose work I have quoted directly. I hope due acknowledgement of this has been made at appropriate places in the text.

In addition the author and publishers wish to acknowledge kind permission given by the following for the inclusion of copyright material:

Center for International Studies, Cornell University, for Figure 3.2, originally published in M. J. Esman, The Landless and Near-Landless in Developing Countries.

UNESCO for extracts from the UNESCO Statistical Yearbooks, 1984, 1986, 1987 and 1988, Trends and Projections of Enrolment by Level of Education and by Age: 1960-2000 (as assessed in 1982), and for Table 8.1, originally published in The Experimental World Literacy Programmes: a Critical Assessment.

United Nations for material from World Population Trends and Policies: 1981 Monitoring Report, vol. I Population Trends; World Population Trends and Policies, Population and Development Interrelations and Population Policies: 1983 Monitoring Reports, vol. I Population Trends (1984); World Population Prospects: Estimates and Projections as Assessed in 1984 
(1986); and Figures 10.1 and 12.1 from the United Nations Chronicle.

United Nations World Population Fund and the New Internationist Magazine for Figures 3.1, 3.3 and 12.2, originally published in the World Population Report, 1988.

World Bank for Figures 1.1, 1.2, 6.1 and 7.1, originally published in the World Development Report, 1988, and for statistical material from that and earlier World Development Reports, copyright 1988 by the International Bank for Reconstruction and Development/The World Bank, reprinted by permission of Oxford University Press.

World Health Organisation for Tables 5.3, 6.1 and 6.2, originally published in the Sixth Report on the World Health Situation 1980, and Evaluation of the Strategy for Health for All: The Seventh Report on the World Health Situation, 1987. An update note was based on the World Health Statistics Annual, 1983.

Penguin Books Ltd for Table 7.5, originally published in Blaug, Layard and Woodhally (1969) The Causes and Consequences of Graduate Unemployment in India.

Every effort has been made to trace all the copyright-holders, but if any have been inadvertently overlooked the publishers will be pleased to make the necessary arrangement at the first opportunity.

Finally may I express my gratitude to the academics, planners and social welfare professionals in the various countries which I have been privileged to visit and work in over the last twenty years; and also to the ordinary people of those countries, the real victims of underdevelopment, who gave me the motivation and the first-hand knowledge I needed to write this book.

HOWARD JONES 